Periodica Polytechnica Chemical Engineering, 63(3), pp. 491-498, 2019

\title{
Antioxidant Capacity of Nettle Leaves During Osmotic Treatment
}

\author{
Violeta Knežević1, Lato L. Pezo², Biljana Lj. Lončar ${ }^{*}$, Vladimir S. Filipović1, Milica R. Nićetin, \\ Stanislava Ž. Gorjanović ${ }^{2}$ Danijela Šuput ${ }^{1}$
}

\footnotetext{
1 Department of Chemical Engineering, Faculty of Technology, University of Novi Sad, Bulevar Cara Lazara 1, 21000 Novi Sad, Serbia

2 Engineering Department, Institute of General and Physical Chemistry, University of Belgrade, Studentski trg 12-16, Serbia

${ }^{*}$ Corresponding author, e-mail: cbiljana@uns.ac.rs
}

Received: 14 June 2018, Accepted: 14 September 2018, Published online: 30 November 2018

\begin{abstract}
Osmotic treatment (OT) of nettle leaves was assessed in various osmotic solutions (sugar beet molasses - SBM and ternary aqueous solution - TAS), at temperatures of 20,35 and $50{ }^{\circ} \mathrm{C}$, under the atmospheric pressure. The influence of the kind of utilized osmotic solution, process temperature and osmotic time on the antioxidant activity (AOC), expressed with the spectrophotometric assays (ABTS, FRAP and DPPH), as well as two direct current polarographic assays, Hydroxo Perhydroxo Mercury (II) complex assay, based on the decrease of anodic current and assay based on the decrease of a cathodic current of $\mathrm{Hg}$ (II) reduction. For determination of the total phenolic content Folin-Ciocalteu assay was used. The Relative Antioxidant Capacity Index (RACI), obtained by setting equal weight for every involved assay was applied in order to get an extensive comparison among analyzed samples and between the used assays. Based on these results, after the OT of nettle leaves in TAS, the AOC decreased, while the OT in SBM increased AOC values. The phenolic antioxidant coefficients (PAC), calculated as the ratio between particular AO capacity and TPC, were used to achieve a more comprehensive comparison between analysed samples, as well as applied assays. The results of RACl evaluation revealed that the most favorable osmotic treatment is the one performed for $5 \mathrm{~h}$ at $35^{\circ} \mathrm{C}$.
\end{abstract}

Keywords

antioxidant activity, nettle leaves, osmotic treatment, sugar beet molasses

\section{Introduction}

Urtica dioica L., well-known as stinging nettle, is annual wild growing weedy plant from Urticaceae botanical family with remarkable biological activity and advantageous influence on human health [1]. Nettles are often found in mellow atmosphere and verdant spots [2]. Foregoing studies show that nettle leaves are a rich source of essential amino acids, ascorbic acid, carbohydrates, phenolic components, tannins, sterols and some mineral elements [2-5]. Considering the fact that stinging nettle leaves are rich in flavonoids, chlorophylls and carotenoids and their degradation products, vitamins [3, 5], proteins [2], mineral materials, organic acids, oil and other components, the stinging nettle is often being used in the folk medicine and in scientific medicine as well $[4,6,7]$.

Stinging nettle over ground parts are applied to the skin for muscle aches and pains, oily scalp, oily hair, and male pattern baldness (alopecia) [8]. Recent demands for natural and organic fibres have increased, although the fibre content of wild nettles is low (about $5 \%$ ), new nettle Clones with a higher fibre content (approximately $17 \%$ ) have been developed to provide good levels of biomass [9].

Antimicrobial and antioxidant activities [4], the potential outcomes for the diminishing of cardiovascular risks [10] and examinations of preventive properties [11] of stinging nettle extracts in breast cancer cells are still investigating.

Variations in chemical composition and the amount of components of stinging nettle are closely related to ecological factors such as temperature, moisture, light, sort of soil and supplements. Among other things, development stages, the harvesting time, form and type of organs, as also the conditions of storage and drying are essential [12].

Osmotic treatment (OT) is as a general pre-treatment step for many processes, used to enhance the nutritional quality, sensory and functional properties of sustenance without interfering its integrity [13]. OT is a water expulsion process, based on soaking food material in a 
hypertonic solution. In contrast with other drying treatments the principal advantages of OT process are water is expelled in liquid form, at mild temperatures and hypertonic solution can be used again $[14,15]$. This procedure also is interesting on the grounds that it provides partial water removal from a food, with low energy consumption and mellow warmth treatment $[16,17]$. In previous research it was shown that sugar beet molasses (SBM) is an exceedingly valuable osmotic solution for treatment of fruits [18], vegetables [15] and meat [19, 20]. SBM contains large quantities of solids ( $>>80 \%$ ), of which around $50 \%$ is sugar, $30-35 \%$ non-sugar compounds and $15-20 \%$ of water. SBM has approximately $50 \%$ saccharose, $1 \%$ raffinose and less than $1 \%$ invert sugar, it additionally contains significant amounts of important micronutrients such as minerals, proteins, vitamins, glutamine acid, organic acids, pectin, etc. [13, 21-23].

The objective of the exhibited work was to examine the impact of osmotic solution type, duration of the process and temperature, on the mass exchange properties amid osmotic treatment of nettle leaves in SBM and TAS. The main aim was to evaluate the effects of osmotic solution, immersion time and temperature, on the antioxidant capacity (AOC) (reported by the values of spectrophotometric assays - ABTS, FRAP and DPPH, as well as two direct current polarographic assays, Hydroxo Perhydroxo Mercury (II) complex assay - HPMC and assay based on the decrease of a cathodic current of $\mathrm{Hg}$ (II) reduction MRAP). Total phenolic content (TPC) was determined by Folin-Ciocalteu assay. It was noticed that the $\mathrm{AO}$ of nettle leaves was increased in SBM solution, and that the DPPH value decreased in TAS, during the OT experiments. Based on results obtained employing all $\mathrm{AO}$ assays, RACI has been calculated. Antioxidant efficiency of phenolics present in analysed samples has been estimated based on $\mathrm{PAC}$, determined as a ratio between particular $\mathrm{AO}$ activity and TPC, and compared to obtain a more comprehensive insight into the activity of analysed samples.

\section{Material and methods}

\subsection{Material}

Samples of stinging nettle leaves were collected in the medow field, near the city of Novi Sad, Serbia $\left(45.2671^{\circ} \mathrm{N}\right.$, $19.8335^{\circ} \mathrm{E}$ ). It was grown in a mild climate grassy area, between the cultivated plants. Nettle leaves samples were cut into squares $(1 \mathrm{x} 1 \mathrm{~cm})$ using kitchen knife. After preparation samples were measured and immersed in hypertonic solutions. Sample to solution ratio was 1:5 which can be considered high enough to neglect the influence of solution concentration changes during the process.

\subsection{Osmotic treatment}

SBM, taken from the sugar manufacturing plant Pećinci, Serbia with introductory dry matter content of $85.04 \% \mathrm{w} / \mathrm{w}$, was diluted to concentrations of $80 \% \mathrm{w} / \mathrm{w}$. The TAS was produced using sucrose in the amount of $1.200 \mathrm{~g} / \mathrm{kg}$ water, $\mathrm{NaCl}$, in the quantity of $350 \mathrm{~g} / \mathrm{kg}$ water and distilled water. TAS was diluted with distilled water to concentrations of $60 \mathrm{w} / \mathrm{w}$.

After each sampling time (30, 60 and 90 minutes) nettle leaf samples were removed from osmotic mediums (SBM and TAS), delicately washed with distilled water, tenderly blotted with paper to expel excessive water from the surface and weighted. The dry substance content of the fresh and treated samples was evaluated by drying at $105{ }^{\circ} \mathrm{C}$ for 24 hours in a heat chamber (Instrumentaria Sutjeska, Croatia). aw of the osmotically treated samples was measured using a water activity measurement device (Testo 650, Germany) with an accuracy of \pm 0.001 at $25{ }^{\circ} \mathrm{C}$. Soluble solids content of the molasses solutions was measured using Abbe refractometer, Carl Zeis, Jenna, at $20{ }^{\circ} \mathrm{C}$. All analytical measurements were carried out in accordance to AOAC (2000). All experiments were repeated three times.

\subsection{Chemicals}

Ethanol or water was used to make working standard solutions $(2.0 \mathrm{mM})$. All chemicals used for the experiment and their origin are described by Gorjanović et al. [24].

\subsection{Total phenolic content}

The Folin-Ciocalteu's reagent was used in order to determine the total content of phenols in the extracts by the spectrophotometrical modified method described by Gorjanović et al. [24].

\subsection{Determination of the spectrophotometric assays and DC polarographic measurements}

Determination of free radical scavenging ability by the use of DPPH radical, total reducing power by (FRAP) and antiradical activity determination by ABTS assay were perfomed by following the procedure reported by Gorjanović et al. [24]. DC polarographic AO assay, use as a basis the diminishing of anodic current of Hydroxo Perhydroxo Mercury (II) complex (HPMC) formation in alkaline solutions of hydrogen peroxide at potential of 
mercury oxidation, and an AO test based on the decrease of DC polarographic cathodic restricting current of mercury (II) reduction in the presence of antioxidants, i.e. mercury reduction antioxidant power (MRAP), were performed as described in Gorjanović et al. [24].

\subsection{Statistical analysis}

The experimental results were presented by the sum of means and standard deviations (SD) for each case. Collected results were subjected to ANOVA to investigate the impacts of process factors. Besides, the two pattern recognition methods, including PCA and CA were applied effectively to classify and separate the different samples. The assessment of ANOVA, PCA and CA of the acquired outcomes was performed using Statistica software version 12 (Statistica, StatSoft Inc. 2012, USA) $^{\circledR}$. The experimental data used for the analysis were derived using the Box and Behnken's fractional factorial (3 level-2 parameter) design, 2 blocks, as indicated by Brlek et al. [25].

\section{Results and discussion}

Changes in antioxidant parameters during osmotic treatment of nettle leaves in TAS and SBM are given in Table 1, respectively. During the experiments, higher temperature and longer processing time lead to an increase of antioxidance capacity in samples osmotically treated using SBM, which is in consistency with various authors [26-28], who reported that molasses can enhance the functionality, safety and health aspects of food to which it is added. The decrease of antioxidant activity was observed for samples dried in TAS. According to Maestro-Durán et al. [29], 12 phenolic compounds were identified in SBM: six benzoic acid (glacial, protocatechin, p-hydroxybenzoic, salicylic, vanillin and saringinine), two cinnamic acids ( $p$-coumarin and ferulin), three phenolic aldehydes hydroxy-benzoic and vanillin aldehyde) and one phenolic alcohol (guaiacol).

Osmotic treatment of nettle leaves at the highest processing time (90 minutes) and temperature $\left(50^{\circ} \mathrm{C}\right)$, lead to decrease of antioxidant capacity for samples dried in TAS: from initial 1.321 to $0.711 \mathrm{mM} \mathrm{Fe}(\mathrm{II})$ for FRAP assay, from 0.965 to $0.473 \mathrm{mM}$ Trolox for ABTS assay, from 0.388 to $0.197 \mathrm{mM}$ Trolox for DPPH assay, from 0.0117 to $0.015 \% \mathrm{~mL}$ for HPMC assay, from 0.016 to $0.015 \% \mathrm{~mL}$ for MRAP assay and from 0.143 to $0.078 \mathrm{mg} \mathrm{GAE} / \mathrm{L}$ for FC. Quite the opposite trend was noticed for samples osmotically treated in SBM, for the same period of time at the highest temperature, the maximum increases of antioxidant capacity were: $1.335 \mathrm{mM}$ Fe(II) for FRAP assay, $0.935 \mathrm{mM}$ Trolox for ABTS assay, $0.392 \mathrm{mM}$ Trolox for DPPH assay, $0.024 \% \mathrm{~mL}$ for HPMC assay, $0.017 \% \mathrm{~mL}$ for MRAP assay and 0.146 for $\mathrm{mg}$ GAE/L FC.

These results are in agreement with the results of the study by Tonon et al. [30], in which it was found that the total carotenoid content of tomatoes was maintained after 6 hours of osmotic treatment in aqueous sucrose and sodium chloride. Also, Shi et al. [31] reported that the reduction of lycopene and $\beta$-carotene in tomato during osmotic treatment in ternary solution is not likely due to the favorable combined effect of sucrose and salt on carotenoid synthesis.

Moreover, according to Atares et al. [32], during the osmotic treatment of the banana in the high concentrated sucrose solution reduces the transport of bioactive

Table 1 Indicators of antioxidant capacity for osmotic treatment of nettle leaves in TAS and SBM osmotic solutions

\begin{tabular}{|c|c|c|c|c|c|c|c|c|c|c|c|c|c|c|}
\hline \multicolumn{3}{|c|}{ Solution } & \multicolumn{6}{|c|}{ TAS } & \multicolumn{6}{|c|}{ SBM } \\
\hline No & $\mathrm{t}$ & $\mathrm{T}$ & FRAP & ABTS & DPPH & HPMC & MRAP & $\mathrm{FC}$ & FRAP & ABTS & DPPH & HPMC & MRAP & $\mathrm{FC}$ \\
\hline & $\min$ & ${ }^{\circ} \mathrm{C}$ & $\begin{array}{c}\mathrm{mM} \\
\mathrm{Fe}(\mathrm{II})\end{array}$ & $\begin{array}{c}\mathrm{mM} \\
\text { Trolox }\end{array}$ & $\begin{array}{c}\mathrm{mM} \\
\text { Trolox }\end{array}$ & $\begin{array}{r}\% \\
\mathrm{~mL}\end{array}$ & $\begin{array}{c}\% \\
\mathrm{~mL}\end{array}$ & $\begin{array}{c}\mathrm{mg} \\
\mathrm{GAE} / \mathrm{L}\end{array}$ & $\begin{array}{c}\mathrm{mM} \\
\mathrm{Fe}(\mathrm{II})\end{array}$ & $\begin{array}{c}\mathrm{mM} \\
\text { Trolox }\end{array}$ & $\begin{array}{c}\mathrm{mM} \\
\text { Trolox }\end{array}$ & $\begin{array}{l}\% \\
\mathrm{~mL}\end{array}$ & $\begin{array}{r}\% \\
\mathrm{~mL}\end{array}$ & $\begin{array}{c}\mathrm{mg} \\
\mathrm{GAE} / \mathrm{L}\end{array}$ \\
\hline 0 & 0 & 20 & $1.321^{\mathrm{g}}$ & $0.965^{\mathrm{g}}$ & $0.388^{\mathrm{h}}$ & $0.017^{\mathrm{d}}$ & $0.016^{\mathrm{a}}$ & $0.143^{\mathrm{f}}$ & $1.321^{\mathrm{a}}$ & $0.965^{\mathrm{a}}$ & $0.388^{\mathrm{a}}$ & $0.017^{\mathrm{a}}$ & $0.016^{\mathrm{a}}$ & $0.143^{\mathrm{a}}$ \\
\hline 1 & 30 & 20 & $1.109^{\mathrm{f}}$ & $0.754^{\mathrm{f}}$ & $0.317^{\mathrm{g}}$ & $0.017^{\mathrm{cd}}$ & $0.015^{\mathrm{a}}$ & $0.117^{\mathrm{e}}$ & $1.323^{\mathrm{a}}$ & $0.937^{\mathrm{a}}$ & $0.396^{\mathrm{a}}$ & $0.019^{\mathrm{b}}$ & $0.016^{\mathrm{ab}}$ & $0.145^{\mathrm{a}}$ \\
\hline 2 & 30 & 35 & $1.009^{\mathrm{e}}$ & $0.677^{\mathrm{e}}$ & $0.281^{\mathrm{e}}$ & $0.016^{\mathrm{bc}}$ & $0.015^{\mathrm{a}}$ & $0.107^{\mathrm{d}}$ & $1.357^{\mathrm{a}}$ & $0.940^{\mathrm{a}}$ & $0.388^{\mathrm{a}}$ & $0.021^{\mathrm{c}}$ & $0.017^{\text {cde }}$ & $0.145^{\mathrm{a}}$ \\
\hline 3 & 30 & 50 & $1.033^{\mathrm{e}}$ & $0.704^{\mathrm{e}}$ & $0.294^{\mathrm{f}}$ & $0.017^{\mathrm{cd}}$ & $0.015^{\mathrm{a}}$ & $0.108^{\mathrm{d}}$ & $1.327^{\mathrm{a}}$ & $0.933^{\mathrm{a}}$ & $0.395^{\mathrm{a}}$ & $0.021^{\mathrm{c}}$ & $0.016^{\text {bcd }}$ & $0.144^{\mathrm{a}}$ \\
\hline 4 & 60 & 20 & $0.926^{\mathrm{d}}$ & $0.641^{\mathrm{d}}$ & $0.266^{\mathrm{d}}$ & $0.016^{\mathrm{bcd}}$ & $0.015^{\mathrm{a}}$ & $0.098^{\mathrm{c}}$ & $1.333^{\mathrm{a}}$ & $0.958^{\mathrm{a}}$ & $0.392^{\mathrm{a}}$ & $0.021^{\mathrm{c}}$ & $0.016^{\mathrm{bc}}$ & $0.146^{\mathrm{a}}$ \\
\hline 5 & 60 & 35 & $0.867^{\mathrm{bc}}$ & $0.591^{\mathrm{bc}}$ & $0.245^{\mathrm{bc}}$ & $0.016^{\mathrm{ab}}$ & $0.015^{\mathrm{a}}$ & $0.091^{\mathrm{b}}$ & $1.338^{\mathrm{a}}$ & $0.957^{\mathrm{a}}$ & $0.396^{\mathrm{a}}$ & $0.023^{\mathrm{d}}$ & $0.017^{\text {cde }}$ & $0.146^{\mathrm{a}}$ \\
\hline 6 & 60 & 50 & $0.885^{\mathrm{cd}}$ & $0.604^{\mathrm{c}}$ & $0.255^{\mathrm{cd}}$ & $0.016^{\text {bcd }}$ & $0.015^{\mathrm{a}}$ & $0.092^{\mathrm{b}}$ & $1.359^{\mathrm{a}}$ & $0.935^{\mathrm{a}}$ & $0.400^{\mathrm{a}}$ & $0.024^{\mathrm{e}}$ & $0.017^{\text {cde }}$ & $0.147^{\mathrm{a}}$ \\
\hline 7 & 90 & 20 & $0.876^{\mathrm{bc}}$ & $0.608^{c}$ & $0.246^{\mathrm{bc}}$ & $0.016^{\mathrm{ab}}$ & $0.015^{\mathrm{a}}$ & $0.092^{\mathrm{b}}$ & $1.348^{\mathrm{a}}$ & $0.937^{\mathrm{a}}$ & $0.390^{\mathrm{a}}$ & $0.022^{\mathrm{d}}$ & $0.017^{\text {cde }}$ & $0.144^{\mathrm{a}}$ \\
\hline 8 & 90 & 35 & $0.834^{b}$ & $0.565^{\mathrm{b}}$ & $0.237^{\mathrm{b}}$ & $0.016^{\mathrm{abc}}$ & $0.015^{\mathrm{a}}$ & $0.089^{\mathrm{b}}$ & $1.358^{\mathrm{a}}$ & $0.957^{\mathrm{a}}$ & $0.388^{\mathrm{a}}$ & $0.024^{\mathrm{e}}$ & $0.017^{\mathrm{de}}$ & $0.146^{\mathrm{a}}$ \\
\hline 9 & 90 & 50 & $0.711^{\mathrm{a}}$ & $0.473^{\mathrm{a}}$ & $0.197^{\mathrm{a}}$ & $0.015^{\mathrm{a}}$ & $0.015^{\mathrm{a}}$ & $0.078^{\mathrm{a}}$ & $1.335^{\mathrm{a}}$ & $0.935^{\mathrm{a}}$ & $0.392^{\mathrm{a}}$ & $0.024^{\mathrm{e}}$ & $0.017^{\mathrm{e}}$ & $0.146^{\mathrm{a}}$ \\
\hline
\end{tabular}

*Different letters written in superscript within the same column in the table show significantly different means of observed data (at $\mathrm{p}<0.05$ ); 0 - control sample; $n=3$ 
compounds from the product to the solution, due to the sucrose barrier created on the surface of the sample, which is responsible for the total actioxidant activity preservation of the product. In addition, the penetration of the osmotic solution into the plant tissue prevents the enzyme-substrate interaction due to the limited concentration of oxygen and moisture in the current enzyme environment, thereby preventing the oxidation of antioxidant compounds through enzymatic activity [33]. Inhibition of possible enzymatic activity, contributes to the preservation of the present antioxidants.

\subsection{Evaluation of relative antioxidant capacity index (RACI) and phenolic antioxidant coefficients (PAC)}

The results expressed by the values of the antioxidant activity assays (FRAP, ABTS, DPPH, HPMC and MRAP) could be compared to the values of the total phenol content determined (expressed by the FC method), and it can be concluded that the antioxidant activity of the treated samples is correlated with the amount of phenol present therein. This confirms that the content of total phenolic compounds contributes to the total antioxidant potential, which coincides to the results of Yao et al. [34] and Zheng et al. [35].

In order to create a complete picture of the ranking of the antioxidant capacities of the OT nettle leaves, a relative antioxidant capacity index (RACI) was calculated by merging the antioxidant capacity values obtained from the different chemical methods. RACI is the mean value of standard scores transformed from the initial data generated by different tests without unit limitation and no variance between methods [36]. According to the results of the classification of samples (Fig. 1) the superiority of the nettle leaves OT in SBM is demonstrated in the totality of tests, giving the highest RACI value of +1.108 after 90 minutes of the treatment at $50{ }^{\circ} \mathrm{C}$. The samples treated in the TAS gave the lowest RACI value $(-1.589)$ after 90 minutes of the treatment at $50{ }^{\circ} \mathrm{C}$. The results have shown that among the OT samples, only the ones osmotically treated in SBM gave a positive value of RACI while samples treated in TAS gave a negative value of RACI for all applied tests. This founding is in accordance with the results of Almeida et al. [37], in which it was demonstrated that the duration of the process is more important than the temperature factor for mechanisms that take place during osmotic treatment (such as the hydrolysis of certain antioxidant compounds and the loss of cell wall integrity), which can lead to a reduction in overall

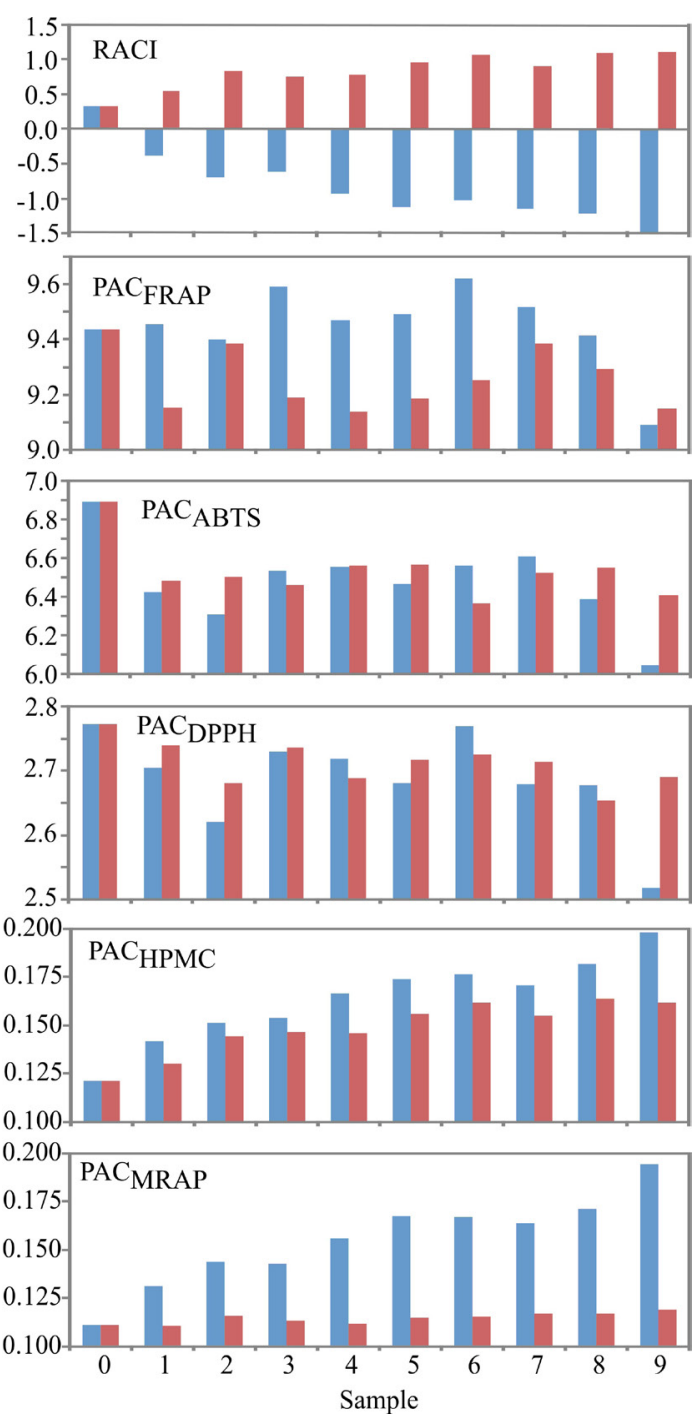

Fig. 1 Relative antioxidant capacity index (RACI) and phenolic antioxidant coefficients (PAC) of plant extracts

antioxidant activity. In order to evaluate the efficiency of the extracted phenolics, the phenol antioxidant coefficient (PAC) was used [38]. PAC of the osmotically treated samples in TAS and SBM was evaluated for quick comparison of antioxidant efficiency of total phenolics using different antioxidant capacity assays.

\subsection{Principal component analysis (PCA)}

Principal component analysis (PCA) is a multivariate analysis procedure used to transform the coordinates of the samples into orthogonal components which are appropriate for data examination. It allows the recognition of patterns in a data series and expressing them in such manner that the similarities and differences can be observed, changing the dimensionality without losing too much information [39]. This technique is used to achieve 
maximum diversity among clusters of parameters and it is characterized by a high degree of flexibility [40, 41]. This procedure is set in such a manner that the highest possible variance has the first component. PCA is giving confirmation to the spatial relation among processing parameters, empowered a separation among samples treated in SBM and TAS as well.

The PCA, applied to the given data set, Table 2, has revealed a clear separation between the spectrophotometric (ABTS, FRAP and DPPH) and polarographic assays. There is also a quite good discrimination between the observed samples, according to used assays. Quality results demonstrate that the first two principal components, accounting for $93.68 \%$ and $6.31 \%$ of the total variability for solution TAS and SBM, can be taken into consideration as a sufficient for data representation. The map of the PCA showed that FRAP (which contributed $17.29 \%$ of total variance, based on correlations), ABTS (17.07\%), DPPH (17.26 \%), FC (17.43 \%), MRAP (15.63\%) and HPMC (15.31\%) have demonstrated a negative score value according to first principal component (Fig. 2). FRAP (which contributed $7.44 \%$ of total variance, based on correlations), ABTS (10.56\%), DPPH (7.82 \%), FC (5.4\%), MRAP (31.99\%) and HPMC $(36.78 \%)$ have also presented the negative influence towards the second principal component.

PCA graphics indicated a quite good discrimination between solutions SBM and TAS solutions. Samples treated with SBM solution are located at the bottom side of the graph, showing increased FRAP, ABTS, DPPH, FC, MRAP and HPMC values. The influence of processing parameters can be seen in Fig. 2, with samples processed with lower immersing time and temperature parameters situated at the at the right side of the graphic.

The results of the PCA analysis coincide to the results of Almeida et al. [37], in which the duration of the process

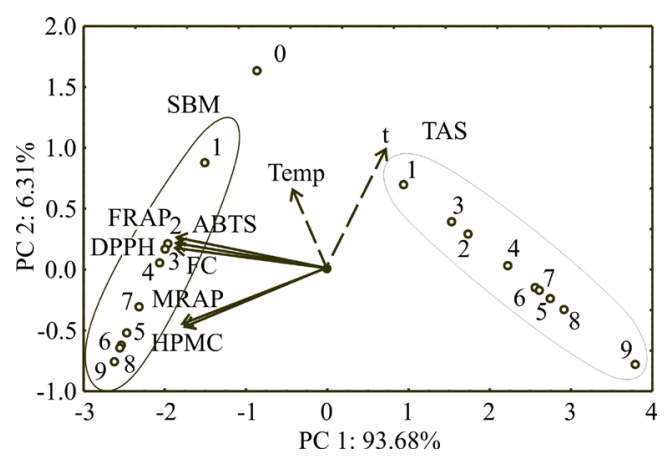

Fig. 2 Graphical presentation of AOC trends in TAS and SBM based on PCA analysis

affects the antioxidant activity of the product more intensively then the temperature factor.

PCA analysis is also confirmed by Nićetin [42], in which the osmotic treatment processing of celery leaves led to lowering the antioxidant activity in the sucrose and sodium chloride solution, and the increase of antioxidant activity in the sugar beet molasses solution.

\subsection{Response Surface Methodology (RSM)}

The performed ANOVA calculation demonstrated the significant effects of independent factors to the responses, and indicated which of responses were significantly influenced by the differing treatment combinations (Table 2).

From Table 2 it can be seen that the greatest influence on the ABTS, DPPH, HPMC and FC in the SOP models has a linear member of processing time, statistically significant at $p<0.01$ level. The influence of the square member of processing time in the SOP model for the prediction of FRAP, ABTS and FC is also noticeable, statistically significant at $\mathrm{p}<0.05$ level. From this table it can be seen that the large influence of the ABTS, DPPH, HPMC and FC in the SOP models has a linear member of processing

Table 2 ANOVA response models FRAP, ABTS, DPPH, HPMC, MRAP and FC for osmotic treatment of nettle leaves in the TAS and SBM osmotic solutions (sum of squares)

\begin{tabular}{cccccccccccccccccccccccc}
\hline \multicolumn{2}{c}{ Solution } & \multicolumn{1}{c}{ SBM } \\
\hline Term & df & FRAP & ABTS & DPPH & HPMC & MRAP & FC & FRAP & ABTS & DPPH & HPMC & MRAP & FC \\
\hline $\mathrm{t}$ & 1 & $0.137^{+}$ & $0.081^{+}$ & $0.012^{+}$ & $7.49 \cdot 10^{-7+}$ & $7.96 \cdot 10^{-8+}$ & $1.43 \cdot 10^{-3+}$ & 0.0001 & 0.0000 & 0.0000 & $1.55 \cdot 10^{-5+}$ & $7.48 \cdot 10^{-7^{*}}$ & $1.72 \cdot 10^{-5+}$ \\
$\mathrm{t}^{2}$ & 1 & $0.010^{* *}$ & $0.010^{*}$ & 0.001 & $2.63 \cdot 10^{-9}$ & $4.63 \cdot \mathrm{E}^{-10}$ & $1.23 \cdot 10^{-4^{*}}$ & 0.0000 & 0.0000 & 0.0001 & $7.34 \cdot 10^{-7}$ & $2.27 \cdot 10^{-9}$ & $1.23 \cdot 10^{-5+}$ \\
$\mathrm{T}$ & 1 & 0.007 & 0.005 & 0.001 & $1.05 \cdot 10^{-8}$ & $1.79 \cdot 10^{-9}$ & $8.83 \cdot 10^{-5 *}$ & 0.0001 & 0.0003 & 0.0000 & $5.19 \cdot 10^{-6^{*}}$ & $3.27 \cdot 10^{-7^{*}}$ & $3.39 \cdot 10^{-7}$ \\
$\mathrm{~T}^{2}$ & 1 & 0.001 & 0.001 & 0.000 & $1.93 \cdot 10^{-8}$ & $6.00 \cdot \mathrm{E}^{-10}$ & $6.14 \cdot 10^{-6}$ & 0.0003 & 0.0002 & 0.0000 & $8.08 \cdot 10^{-7}$ & $1.36 \cdot 10^{-7}$ & $1.27 \cdot 10^{-7}$ \\
$\mathrm{t} \times \mathrm{T}$ & 1 & 0.002 & 0.001 & 0.000 & $2.85 \cdot 10^{-9}$ & $4.74 \cdot 10^{-9 *}$ & $5.49 \cdot 10^{-6}$ & 0.0001 & 0.0001 & 0.0000 & $4.02 \cdot 10^{-8}$ & $8.99 \cdot 10^{-10}$ & $1.28 \cdot 10^{-6}$ \\
Error & 3 & 0.006 & 0.005 & 0.001 & $3.55 \cdot 10^{-7}$ & $2.71 \cdot 10^{-9}$ & $3.97 \cdot 10^{-5}$ & 0.0009 & 0.0006 & 0.0000 & $1.11 \cdot 10^{-6}$ & $1.52 \cdot 10^{-7}$ & $1.56 \cdot 10^{-6}$ \\
$\mathrm{r}^{2}$ & & 0.978 & 0.974 & 0.966 & 0.774 & 0.986 & 0.986 & 0.580 & 0.492 & 0.782 & 0.979 & 0.930 & 0.955 \\
\hline
\end{tabular}


time, statistically significant at $p<0.01$. The influence of the square member of processing time in the SOP model for the prediction of ABTS and FC is also noticeable, statistically significant at $\mathrm{p}<0.05$ level.

Table 2 shows the ANOVA calculation of the developed SOP models for the responses FRAP, ABTS, DPPH, HPMC, MRAP and FC for the osmotically treated nettle leaves in the SBM. From this table it can be seen that linear members of temperature and processing time are statistically significant at of $p<0.05$ level (except for the influence of the linear member of process time on HPMC, statistically significant at $\mathrm{p}<0.01$ level) in the SOP model for calculating HPMC and MRAP. In SOP models for calculating the $\mathrm{FC}$, linear and quadratic members of processing time have the greatest influence, statistically significant at $\mathrm{p}<0.01$ level.

A significant lack of fit generally demonstrates that the model failed to represent the data in the experimental domain at which points were not included in the regression All SOP models had an insignificant lack of fit tests, which implies that all the models represented the data satisfactorily. The coefficient of determination, $\mathrm{r}^{2}$, is defined as the ratio of the explained variation to the total variation and is explained by its magnitude [43]. The $\mathrm{r}^{2}$ values for FRAP (0.580), ABTS (0.492), DPPH (0.782), HPMC $(0.979)$, MRAP $(0.930)$ and FC (0.955) were very good and show the good fit of the model to experimental results.

\section{References}

[1] Đurović, S., Pavlić, B., Šorgić, S., Popov, S., Savić, S., Pertonijević, M., Radojković, M., Cvetanović, A., Zoran, Z. "Chemical composition of stinging nettle leaves obtained by different analytical approaches", Journal of Functional Foods, 32, pp. 18-26, 2017.

https://doi.org/10.1016/j.jff.2017.02.019

[2] El Haouari, M., Bnouhm, M., Bendahou, M., Aziz, M., Ziyyat, A., Legssyer, A., Mekhfi, H. "Inhibition of Rat Platelet Aggregation by Urtica dioica Leaves Extracts", Phytotherapy Research, 20(7), pp. 568-572, 2006.

https://doi.org/10.1002/ptr.1906

[3] Taylor, K. "Biological Flora of the British Isles: Urtica dioica L, Journal of Ecology, 97(6), pp. 1436-1458, 2009. https://doi.org/10.1111/j.1365-2745.2009.01575.x

[4] Kukrić, Z., Topalić-Trivunović, Lj., Kukavica, B. M., Matoš, S. B., Pavičić, S. S., Boroja M. M., Savić A. V. "Characterization of antioxidant and antimicrobial activities of nettle leaves (Urtica dioica L.)", Acta Periodica Technologica, 43, pp. 257-272, 2012. https://doi.org/10.2298/APT1243257K

[5] Rafajlovska, V., Kavrakovski, Z., Simonovska, J., Srbinoska, M. "Determination of protein and mineral contents in stinging nettle", Quality of Life, 4(1-2), pp. 26-30, 2013.

https://doi.org/10.7251/QOL1301026R
On the basis of the observed parameters in this investigation, the optimum conditions for osmotic treatment of nettle leaves in SBM could be an immersion time of 60 minutes and osmotic solution temperature of $50{ }^{\circ} \mathrm{C}$. On the other hand, the osmotic treatment in TAS is not acceptable considering the fact that it leads to the constant decrease in antioxidant capacity for all observed process conditions and assays. This is in accordance with the claim that sugar beet molasses as an osmotic solution possess strong antioxidant potential, confirmed by Nićetin et al. [36].

\section{Conclusion}

The decrease of AO was observed during osmotic treatment in TAS (DPPH value was decreased from initial 0.388 to 0.199 , while HPMC value decreased from 0.017 to 0.015 ), while the increase of $\mathrm{AO}$ was noticed using SBM solution (DPPH value was increased to 0.019 , and HPMC was increased to 0.024). The optimum conditions for osmotic treatment of nettle leaves in SBM could be an immersion time of 60 minutes and osmotic solution temperature of $50^{\circ} \mathrm{C}$. While, the osmotic treatment in TAS is not acceptable considering the fact that it leads to the constant decrease in AOC for all observed process conditions and assays. The results have shown that among the OT samples, only the ones osmotically treated in SBM gave a positive value of RACI while samples treated in TAS gave a negative value of RACI for all applied tests.

[6] Rafajlovska, V., Djarmati, Z., Najdenova, V., Cvetkov, Lj. "Extraction of stinging nettle (Urtica dioica 1.) with supercritical carbon dioxide", Journal of Balikesir University Institute of Science and Technology, 4(2), pp. 49-52, 2002. [online] Available at: http://fbed.balikesir.edu.tr/index.php/dergi/article/ view/232/213 [Acessad: 30 January 2018]

[7] Stanojević, Lj., Zdravković, A., Stanković, M., Cakić Milorad, M., Nikolić V. D., Ilić, D. P. "Antioksidativna aktivnost vodeno-etanolnih ekstrakata iz lista koprive (Urtica dioica L.)" (The antioxidant activity of aqueous-ethanolic extracts from nettle leaf (Urtica dioica L.)), Savremene tehnologije, 2(1), pp. 51-59, 2013. (in Serbian) [online] Available at: https://scindeks.ceon.rs/article. aspx?artid=2217-97121301051S [Accessed: 30 January 2018]

[8] Riehemann, K., Behnke B., Schulze-Osthoff, K. "Plant extracts from stinging nettle (Urtica dioca), an antirheumatic remedy, inhibit the proinflammatory transcription factor NF- $\kappa B$, FEBS Letters, 442(1), pp. 89-94, 1999. https://doi.org/10.1016/S0014-5793(98)01622-6

[9] Baverstock, J., Porcel, M., Clark, S. J., Copeland, J. E., Pell, J. K. "Potential value of the fiber nettle Urtica dioica as a resource for the nettle aphid Microlophium carnosum and its insect and fungal natural enemies", BioControl, 56(2), pp. 215-223, 2011.

https://doi.org/10.1007/s10526-010-9330-x 
[10] Alisi, C. S., Emejulu, A. A., Alisi, P. N. C., Nwaogu, L. A., Onyema, O. O. "Decreased cardiovascular risk and resistance to hyperlipemia-induced hepatic damage in rats by aqueous extract of Urtica dioica", African Journal of Biochemistry Research, 2(4), pp. 102-106, 2008. [online] Available at: http://www.academicjournals.org/article/article1380023553_Alisi\%20et\%20al.pdf [Accessed: 30 January 2018]

[11] Güler, E. "Investigation of chemopreventive properties of Urtica Dioica L., in MCF-7 and MDA231 breast cancer cell lines", PhD Thesis, Middle East Technical University, 2011. [online] Available at: http://citeseerx.ist.psu.edu/viewdoc/download?doi=10.1.1.633.2960\&rep=rep1\&type=pdf [Accessed: 30 January 2018]

[12] Biesiada, A., Kucharska, A., Sokół-Łętowska, A., Kuś, A. "Effect of the Age of Plantation and Harvest Term on Chemical Composition and Antioxidant Avctivity of Stinging Nettle (Urtica dioica L.), Ecological Chemistry and Engineering. A, 17(9), pp. 1061-1068, 2010. [online] Available at: http://yadda. icm.edu.pl/yadda/element/bwmeta1.element.baztech-article-BPG8-0060-0014 [Accessed: 30 January 2018]

[13] Mišljenović, N. M., Koprivica, G. B., Pezo, L. L., Kuljanin, T. A., Bodroža Solarov, M. I., Filipčev, B. V. "Application of Peleg model to study mass transfer during osmotic dehydration of apple in ugar beet molasses", Acta Periodica Technologica, 42, pp. 91-100, 2011. https://doi.org/10.2298/APT1142091M

[14] Ćurčić, B., Lević, Lj., Filipović, V., Nićetin, M., Knežević, V., Pezo, L., Šuput, D. "Osmotsko sušenje karaša (Carassius carassius) primenom rastvora Melase šećerne repe" (Osmotic drying of crucian carp (Carrassius carrassius) using SBM solutions), Journal on Processing and Energy in Agriculture, 16(4), pp. 173-175, 2012. [online] Available at: http://scindeks.ceon.rs/article.aspx?query $=$ ISSID $\% 26$ and $\% 2611150$ \&page $=7 \&$ sort $=8 \&$ stype $=0$ \&backurl $=\% 2$ fissue.. spx $\% 3$ fissue $\% 3 \mathrm{~d} 11150$ [Accessed: 30 January 2018]

[15] Mišljenović, N. M., Koprivica, G. B., Pezo, L. L., Lević, Lj. B., Ćurčić B. Lj., Filipović, V. S., Nićetin, M. R. "Optimization of the osmotic dehydration of carrot cubes in sugar beet molasses", Thermal Science, 16(1), pp. 43-52, 2012. [online] Available at: http://thermalscience.vinca.rs/pdfs/papers-2011/ TSCI110808129M.pdf [Accessed: 30 January 2018]

[16] Manivannan, P., Rajasimman, M. "Optimization of process parameters for the osmotic dehydration of beetroot in sugar solution". Journal of Food Engineering, 34(3), pp. 804-825, 2011. https://doi.org/10.1111/j.1745-4530.2009.00436.x

[17] Vieira, G. S., Pereira, L. M., Hubinger, M. D. "Optimisation of osmotic dehydration process of guavas by response surface methodology and desirability function", International Journal of Food Science and Technology, 47(1), pp. 132-140, 2012. https://doi.org/10.1111/j.1365-2621.2011.02818.x

[18] Koprivica, G. D., Pezo, L. L., Ćurčić, B. L., Lević, Lj. B., Šuput, D. Z. "Optimization of Osmotic Dehydration of Apples in Sugar Beet Molasses", Journal of Food Processing and Preservation, 38(4), pp. 1705-1715, 2014. https://doi.org/10.1111/jfpp.12133
[19] Filipović, V. S., Ćurčić, B. Lj., Nićetin, M. R., Plavšić, D. V., Koprivica, G. B., Mišljenović, N. M. "Mass transfer and microbiological profile of pork meat dehydrated in two different osmotic solutions", Hemijska industrija, 66(5), pp. 743-748, 2012. https://doi.org/10.2298/HEMIND120130033F

[20] Pezo, L. L., Ćurčić, B. Lj., Filipović, V. S., Nićetin, M. R., Koprivica, G. B., Mišljenović, N. M., Lević, Lj. B. "Artificial neural network model of pork meat cubes osmotic dehydration", Hemijska industrija, 67(3), pp. 465-475, 2013. https://doi.org/10.2298/HEMIND120529082P

[21] Šuput, D. Z., Lazić, V. L., Pezo, L. L., Lević, Lj. B., Gubić, J. M., Hromiš, N. M., Šojić, B. V. "Modified atmosphere packaging and osmotic dehydration effect on pork quality and stability", Romanian Biotechnological Letters, 18(2), pp. 8160-8169, 2013. [online] Available at: https://www.rombio.eu/vol18nr2/11\%20 Suput.pdf [Accessed: 30 January 2018]

[22] Filipčev, B. "Nutritivni profil, antioksidacioni potencijal i senzorni kvalitet specijalnih vrsta hlebova sa dodatkom melase šećerne repe" (Nutrition profile, antioxidative potential and sensory quality of bread supplemented with SBM), PhD Thesis, University of Novi Sad, 2009. (in Serbian) [online] Available at: https://www. cris.uns.ac.rs/searchDissertations.jsf [Accessed: 30 January 2018]

[23] Filipčev, B., Lević, Lj., Bodroža-Solarov, M., Mišljenovic, N., Koprivica, G. "Quality Characteristics and Antioxidant Properties of Breads Supplemented with Sugar Beet Molasses-Based Ingredients", International Journal of Food Properties, 13(5), pp. 1035-1053, 2010. https://doi.org/10.1080/10942910902950526

[24] Gorjanović, S., Komes, D., Pastor, F. T., Belščak-Cvitanović, A., Pezo, L., Hećimović, I., Sužnjević, D. "Antioxidant Capacity of Teas and Herbal Infusions: Polarographic Assessment", Journal of Agricultural and Food Chemistry, 60(38), pp. 9573-9580, 2012. https://doi.org/10.1021/jf302375t

[25] Brlek, T., Pezo, L., Voća, N., Krička, T., Vukmirović, Đ., Čolović, R., Bodroža-Solarov, M. "Chemometric approach for assessing the quality of olive cake pellets", Fuel Processing Technology, 116, pp. 250-256, 2013.

https://doi.org/10.1016/j.fuproc.2013.07.006

[26] Nagai, Y., Mizutani, T., Iwabe, H., Araki, S., Suzuki, M. "Physiological functions of sugar cane extracts", In: Proceedings of the 60th Annual Meeting of Sugar Industry Technologists in Taiwan, Taipei, Taiwan, pp. 97-104, 2001.

[27] Takara, K., Ushijima, K., Wada, K., Iwasaki, H., Yamashita, M. "Phenolic Compounds from Sugarcane Molasses Possessing Antibacterial Activity against Cariogenic Bacteria", Journal of Oleo Science, 56(11), pp. 611-614. 2007. [online] Available at: http://www. panelamonitor.org/media/docrepo/document/files/phenolic-compounds-from-sugarcane-molasses-possessing-antibacterial-activity-against-cariogenic-bacteria.pdf [Accessed: 30 January 2018]

[28] Guimarães, C. M., Gião, M. S., Martinez, S. S., Pintado, A. I., Bento, L. S., Malcata, F. X. "Antioxidant Activity of Sugar Molasses, Including Protective Effect Against DNA Oxidative Damage", Journal of Food Science, 72(1), pp. C039-C043, 2007. https://doi.org/10.1111/j.1750-3841.2006.00231.x 
[29] Maestro-Durán, R., Borja, R., Jiménez, A. M., León, M. M. "Phenolic compounds in sugar beet molasses", Agrochimica, 40, pp. 173-179, 1996.

[30] Tonon, R. V., Baroni, A. F., Hubinger, M. D. "Osmotic dehydration of tomato in ternary solution: Influence of process variables on mass transfer kinetics and an evaluation of the retention of carotenoids", Journal of Food Engineering, 82(4), pp. 509-517, 2007. https://doi.org/10.1016/j.jfoodeng.2007.03.008

[31] Shi, J., Le Maguer, M., Kakuda., Y., Lipaty, A., Niekamp, F. "Lycopene degradation and isomerisation in tomato dehydration", Food Research International, 32(1), pp. 15-21, 1999. https://doi.org/10.1016/S0963-9969(99)00059-9

[32] Atares, L., Sousa Gallagher M. J., Oliveira, F. A. R. "Process conditions effect on the quality of banana osmotically dehydrated", Journal of Food Engineering, 103(4), pp. 401-408, 2011. https://doi.org/10.1016/j.jfoodeng.2010.11.010

[33] Landim, A. P. M., Barbosa, M. I. M. J., Barbosa Jr., J. L. "Influence of osmotic dehydration on bioactive compounds, antioxidant capacity, color and texture of fruits and vegetables: a review", Ciência Rural, 46(10), pp. 1714-1722, 2016. https://doi.org/10.1590/0103-8478cr20150534

[34] Yao, Y., Ren, G. "Effect of thermal treatment on phenolic composition and antioxidant activities of two celery cultivars", LWT - Food Science and Technology, 44(1), pp. 181-185, 2011. https://doi.org/10.1016/j.1wt.2010.07.001

[35] Zheng, W., Wang, S. Y. "Antioxidant Activity and Phenolic Compounds in Selected Herbs", Journal of Agricultural and Food Chemistry, 49(11), pp. 5165-5170, 2001. https://doi.org/10.1021/jf010697n

[36] Nićetin, M. R., Pezo, L. L., Lončar, B. Lj., Filipović, V. S., Šuput, D. Z., Knežević V. M., Filipović, J. S. "The possibility of increasing the antioxidant activity of celery root during osmotic treatment", Journal of the Serbian Chemical Society, 82(3), pp. 253-265, 2017. https://doi.org/10.2298/JSC161020015N

[37] Almeida, J. A. R., Mussi, L. P., Oliveira, D. B., Pereira, N. R. "Effect of Temperature and Sucrose Concentration on the Retention of Polyphenol Compounds and Antioxidant Activity of Osmotically Dehydrated Bananas", Journal of Food Processing and Preservation, 39(6), pp. 1061-1069, 2015.

https://doi.org/10.1111/jfpp.12321
[38] Sun, T., Tanumihardjo, S. A. "An Integrated Approach to Evaluate Food Antioxidant Capacity", Journal of Food Science, 72(9), pp. R159-R165, 2007. https://doi.org/10.1111/j.1750-3841.2007.00552.x

[39] Hodzic, Z., Pasalic, H., Memisevic, A., Srabovic, M., Saletovic, M., Poljakovic, M. "The Influence of Total Phenols Content on Antioxidant Capacity in the Whole Grain Extracts", European Journal of Scientific Research, 28(3), pp. 471-477, 2009. [online] Available at: https://pdfs.semanticscholar.org/750c/4e6e90ca5cc77a68299111bb263b8ed841f9.pdf [Accessed: 30 January 2018]

[40] de Souza, C. T., Soares, S. A. R., Queiroz, A. F. S., dos Santos, A. M. P, Ferreira, S. L. C. "Determination and evaluation of the mineral composition of breadfruit (Artocarpus altilis) using multivariate analysis technique", Microchemical Journal, 128, pp. 84-88, 2016. https://doi.org/10.1016/j.microc.2016.04.001

[41] Abdi, H. Williams, L. J. "Principal component analysis", Wiley Interdisciplinary Reviews: Computational Statistics, 2(4), pp. 433459,2010 https://doi.org/10.1002/wics.101

[42] Nicetin, M. "Efekti osmotske dehidratacije na poboljšanje održivosti, nutritivna i antioksidativna svojstva korena i lista celera (Apium graveolens)" (Effects of osmotic dehydration on improving sustainability, nutritive and antioxidative properties of celery leaves and root (Apium graveolens)), $\mathrm{PhD}$ Thesis, University of Novi Sad, 2017. (in Serbian)

[43] Ćurčić, B. L., Pezo, L. L., Filipović, V. S., Nićetin, M. R., Knežević, V. "Osmotic Treatment of Fish in Two Different Solutions-Artificial Neural Network Model", Journal of Food Processing and Preservation, 39(6), pp. 671-680, 2015. https://doi.org/10.1111/jfpp.12275 